\title{
The Ways To Promote Wellness Tourism In Muang District, Chachoengsao Province
}

\author{
Noppadol Dharawanij \\ College of Tourism and Hospitality \\ Rangsit University \\ Pathumthani, Thailand \\ dharawanij@gmail.com
}

\begin{abstract}
The study has 3 purposes: 1. to study wellness tourism in Muang district, Chachoengsao province, 2. to study the government policy and support wellness tourism in Muang district, Chachoengsao province, and 3. to study all private businesses which provide wellness tourism in Muang district, Chachoengsao province to increase the number of tourists and revenue to all businesses.
\end{abstract}

In the process of making this research, two techniques a qualitative technique and a quantitative technique were applied. In the qualitative technique, the researcher used the interview to be study tool by purposive sampling with the director and 10 officers in Tourism Authority of Thailand, Chachoengsao office; director and 10 officers of Tourism and sport, Chachoengsao office; 20 owners of and staffs of hotels and resorts provide wellness tourism, head of district administration office and his consultants; and private businesses which provide wellness tourism. As for the quantitative technique, the researcher carried out a random accidental sampling method to study 400 Thai tourists and 100 foreign tourists, and 100 people who living in the community nearby; the study tool is questionnaire and statistical analysis in frequency distribution, average, percentage and standard deviation; hypothesis testing by (SPSS).

As a result, the researcher's outcomes are as the follows:

1. There are 2 main types of wellness tourism in Muang district, Chachachoengsao province which is physical and spiritual. For the physical wellness tourism is aromatherapy, healthy food, massage, and spa; the spiritual wellness tourism is monk's chat and meditation in the temple which can relieve their tension and mind.

2. The government policy and support all tourists to visit some main tourism resources in Muang district, Chachoengsao province such as Sotornwararam royal temple, Samanratanaram temple etc. followed by take a rest in hotels or resorts for their physical wellness and do spiritual wellness tourism in the temple due to the short distance of traveling from Bangkok to Chachoengsao province (about 80 kilometers) and the 5'A of factors represent the essential requirements of successful tourism: Attractions $(\bar{x}$ = 4.33), Access $(\bar{x}=4.52)$, Accommodation $(\bar{x}=$ 4.37), Amenities $(\bar{x}=4.23)$, and Activities $(\bar{x}=$ 4.63) are very well to serve all tourists.

3. Both Thai and foreign tourists want to come to Muang district, Chachoengsao province for their relaxation and get better healthy both physical wellness in the hotels and resorts which increasing the number of tourists and revenue to the business and spiritual wellness in the temple which also increasing number of tourists not only Buddhist but also different religions especially in Sotornwararam royal temple and donate more money to the temple. All the businesses which provide tourism businesses in Muang district also make more revenue.

These results served the need of many people travel for rest and relaxation, while a significant number of people also arrive in Thailand to address a medical need of varying urgency. Wellness tourism sits somewhere in between those two drivers of travel. It other locations, wellness tourism is often seen in the form of destination spas. These places feature resort or hotel like conditions but offer a range of holistic health and wellbeing services on-site. People choose these places, not as a simple place of accommodation, but as their main purpose of the holiday. (Pacific Prime Thailand, 2018) Actually, Thailand is ranked 13th in the world and 4th in Asia after China, Japan and India and wellness tourism is an important driver of Thailand's tourism sector, wellness tourism is a star in tourism businesses with over 7\% annual growth during 2013-2015. Its market is valued at 320 billion baht. (Pullawat Pitigraisorn, 2017) Even, there are top 10 of wellness tourism in Thailand, however the locations are too far away mostly are in the southern or the northern part of Thailand and served the rich or classy people. (Luxury Society Asia, 2018) Wellness tourism in Chachoengsao province not only challenge all of the top ten destinations because most of the resorts and hotels provide the wellness service in lower cost and the distance of travel from Bangkok is also very short distance but also can become the new wellness destination in Thailand.

Keywords-Wellness Tourism, Medium Class Wellness Tourism

\section{INTRODUCTION}

This template, Thailand can be divided into 5 parts: Northern part, Central part, Northeast part, Eastern part, and southern part. There are 77 provinces altogether, each of province, there are many tourist attractions spread all over the area. The government tries to promote tourism in Thailand to be grown accordingly. Tourism industry makes a lot of benefit and revenue to the country continuously by the supporting of Tourism authority of Thailand, ministry of tourism and sport and private enterprises such as hotel accommodation, tour operators, food and restaurants, souvenirs business, tourist attraction businesses, and related service businesses. 
Chachoengsao province is the province in central part of Thailand and it is located near Bangkok approximately 80 kilometers away, one can drive to Chachoengsao within 11.30 hours. Most of tourists always travel passes the province and makes only a brief stop and continue to other destinations. This province becomes the bypass city only some tourists with specific reasons make stop overnight in the province, the rest will continue to their destinations. In fact, Chachoengsao province itself used to be ancient town located to the east direction of the old capital of Ayutthaya period. According to chronicle, the province was established since king Boromtrailokanat (king number 8 of Ayutthaya period) and later by the reign of king Rama VI, the ancient city became the province in 1916. Nowadays, there are so many variety of tourist attractions: historical and cultural tourist attractions such as Sotornwararam temple which Sotorn principal Buddha image, the most revered among Thai Buddhist people was enshrined in the ordination hall, forts and walls built in the reign of king Rama III, city pillar shrines, Pitularatrangsarit temple, Chinprachasmosorn temple built in the reign of king Rama V, and Samarnrattanaram temple where the largest Bhikanes image of Thailand in attitude of happiness enshrined etc., natural tourist attractions such as Bangpakong river originated from Sankampaeng mountain range flow through Prachinburi province and to Chachoengsao then to gulf of Thailand about 230 kilometers long, man-made tourist attractions such as 100 years old Ban Mai market located by the river, zone type Bangpakong dam 2,500 meters long and 24 meters high etc.

Although, there are so many diversity number of tourist attractions in Chachoengsao province but according to website (Skyscanner, top 10 hit provinces of Thailand 2016) states that the first top 10 provinces of Thailand is 1 . Bangkok 2. Chiang Mai 3. Phuket 4. Songkhla 5. Krabi 6. Udonthani 7. Ubonratchathani 8. Chiangrai 9. Suratthani and 10. Khonkaen. In Chachoengsao province, there are 2,984,298 tourists visited with the revenue of 4,160.71 million Baht (Department of Tourism, tourist statistic, 2016) and the average stay is 1.87 days which is small number of tourists. Actually, Chachoengsao province is located near Bangkok which is the most number of tourists visited due to no one study the real potential of tourism in the province which can serve the need of tourists who come to visit to this province.

Researcher, therefore, selected Chachoengsao province to study the ways to promote Wellness Tourism because of its location, costs, and the service standard of hotel accommodations.

modified in MS Word 2007 and saved as a "Word 972003 Document" for the PC, provides authors with most of the formatting specifications needed for preparing electronic versions of their papers. All standard paper components have been specified for three reasons: (1) ease of use when formatting individual papers, (2) automatic compliance to electronic requirements that facilitate the concurrent or later production of electronic products, and (3) conformity of style throughout a conference proceedings. Margins, column widths, line spacing, and type styles are built-in; examples of the type styles are provided throughout this document and are identified in italic type, within parentheses, following the example. Some components, such as multi-leveled equations, graphics, and tables are not prescribed, although the various table text styles are provided. The formatter will need to create these components, incorporating the applicable criteria that follow.

\section{The main content}

Researcher used questionnaire as a tool for quantitative research by accidental sampling 400 Thai tourists and 100 foreign tourists, 5 managers at least 5 years experienced in tour operators business and 10 tour operators staffs, 5 managers and 5 hotel staffs in hotel accommodation business, and 5 managers and 5 staffs of related service provider business. Qualitative research used interview as a tool by purposive sampling 5 heads of community in Muang district, a supervisor of Tourism Authority of Thailand and 1 staff, a director of Tourism Authority of Thailand, Chachoengsao province, and a director of tourism and sport, Chachoengsao office.

Researcher found the findings as the follows:

1. There are 2 main types of wellness tourism in Muang district, Chachachoengsao province which is physical and spiritual. For the physical wellness tourism is aromatherapy, healthy food, massage, and spa; the spiritual wellness tourism is monk's chat and meditation in the temple which can relieve their tension and mind.

2. The government policy and support all tourists to visit some main tourism resources in Muang district, Chachoengsao province such as Sotornwararam royal temple, Samanratanaram temple etc. followed by take a rest in hotels or resorts for their physical wellness and do spiritual wellness tourism in the temple due to the short distance of traveling from Bangkok to Chachoengsao province (about 80 kilometers) and the 5'A of factors represent the essential requirements of successful tourism: Attractions $(\bar{x}=4.33)$, Access $(\bar{x}=4.52)$, Accommodation $(\bar{x}=4.37)$, Amenities $(\bar{x}=4.23)$, and Activities $(\bar{x}=4.63)$ are very well to serve all tourists.

3. Both Thai and foreign tourists want to come to Muang district, Chachoengsao province for their relaxation and get better healthy both physical wellness in the hotels and resorts which increasing the number of tourists and revenue to the business and spiritual wellness in the temple which also increasing number of tourists not only Buddhist but also different religions especially in Sotornwararam royal temple and donate more money to the temple. All the businesses which provide tourism businesses in Muang district also make more revenue.

Researchers also found that Muang district; Chachoengsao province should improve the following to be a wellness center:

\section{Infrastructure}

Both Thai and foreign tourists and all related entrepreneurs should improve the accessibility to tourist attractions: signage, sign board, food and beverage services, public 
service and hotel accommodation services which will serve the concept of infrastructure improvement by the government, however, the lack of personnel and cooperation of private enterprises and government units cooperation.

2. Tourist activities

Both Thai and foreign tourists and all related entrepreneurs need all tourism activities in medium level such as cruising along Bangpakong river activities, health tourism activities, and local cultural performance activities accordant to government to promote more tourism activities to attract more tourists to come to the province especially health or wellness tourism activities.

3. Tourism qualities

Both Thai and foreign tourists and all related entrepreneurs need to improve the service of local tour operators, cleanliness if places, the comfort and convenience of hotel accommodation, quality and cleanliness of food shops and restaurants, and the quality of souvenirs and shops accordant to the government, however well management and cooperation of private enterprises still not well cooperated.

4. Tourism services

Both Thai and foreign tourists and all related entrepreneurs need to improve officers who provide tourist information, give direction to tourism and suggest tour routing to be accuracy and clearly to all tourists and also improve theirs foreign languages especially English and Chinese.

5. Public welfare and security

Both Thai and foreign tourists and all related entrepreneurs need asset and lives security checks in tourist area.

Researcher also do SWOT analysis of wellness tourism in Chachoengsao province and the results are as the following:

Table 1. SWOT Analysis

\begin{tabular}{|l|l|}
\hline \multicolumn{1}{|c|}{$\begin{array}{c}\text { Internal } \\
\text { factors }\end{array}$} & \multicolumn{1}{|c|}{ Strengths (S) } \\
\hline & $\begin{array}{l}\text { 1. Muang district, } \\
\text { Chachoengsao } \\
\text { province is in short } \\
\text { distance from } \\
\text { Bangkok (about } 80 \\
\text { km.). Travel from } \\
\text { Bangkok is very } \\
\text { easy, there are many } \\
\text { connected routes } \\
\text { and not only travel } \\
\text { by car or bus, but } \\
\text { also travel by train is } \\
\text { comfort and } \\
\text { convenience as well. } \\
\text { 2. There are many } \\
\text { diversity of tourist } \\
\text { attractions which } \\
\text { serve the need of } \\
\text { both Thai and } \\
\text { foreign tourists } \\
\text { especially health or }\end{array}$ \\
\hline
\end{tabular}

Weaknesses (W)

1. Public utility is not completely ready, it needs to be improved.

2. Trash collection system is not perfect and the number of trash boxes are not enough makes the area not quite tidy. 3. Most of tour operators are not operate and sell the tour programs to the province. 4. Most of related tourism enterprises are not well cooperated to attract tourists to

\begin{tabular}{|c|c|c|}
\hline & $\begin{array}{l}\text { wellness tourism, } \\
\text { historical, cultural } \\
\text { and natural, } \\
\text { 3. There are variety } \\
\text { of tourism activities } \\
\text { according to tourist } \\
\text { attractions to serve } \\
\text { the need of all } \\
\text { tourists. }\end{array}$ & $\begin{array}{l}\text { come to visit the } \\
\text { province. } \\
5 . \text { Lack of } \\
\text { specialists to } \\
\text { promote and } \\
\text { public relations of } \\
\text { the province. }\end{array}$ \\
\hline $\begin{array}{l}\text { External } \\
\text { factors }\end{array}$ & Opportunities (O) & Threats (T) \\
\hline & $\begin{array}{l}\text { 1.There are many } \\
\text { and diversity of } \\
\text { tourist attractions in } \\
\text { Muang District, } \\
\text { Chachoengsao } \\
\text { province; therefore } \\
\text { tourism activities } \\
\text { can varies and } \\
\text { attract to all tourists, } \\
\text { however, } \\
\text { cooperation among } \\
\text { all related } \\
\text { organization should } \\
\text { be complied. } \\
\text { 2. There are many } \\
\text { hotel } \\
\text { accommodations in } \\
\text { different levels. It } \\
\text { size and type also } \\
\text { variable, therefore } \\
\text { hotel } \\
\text { accommodation } \\
\text { should be } \\
\text { concentrated in } \\
\text { organizing meeting, } \\
\text { convention and also } \\
\text { health or wellness } \\
\text { tourism to draw } \\
\text { attention to all } \\
\text { tourists and received } \\
\text { more revenues to the } \\
\text { businesses and the } \\
\text { area. } \\
\text { 3. In Muang district, } \\
\text { Chachoengsao } \\
\text { province should } \\
\text { promote health or } \\
\text { wellness tourism } \\
\text { both physical and } \\
\text { spiritual to all } \\
\text { tourists and used } \\
\text { temple for spiritual } \\
\text { center such as monk } \\
\text { chat and meditation } \\
\text { and hotel } \\
\text { accommodation for } \\
\text { physical center such }\end{array}$ & $\begin{array}{l}\text { 1. There is no } \\
\text { support by all } \\
\text { related } \\
\text { organizations both } \\
\text { governments and } \\
\text { private. If there is } \\
\text { support, tourism in } \\
\text { Chachoengsao will } \\
\text { be well-known } \\
\text { among all tourists } \\
\text { and tourism } \\
\text { potential of the } \\
\text { province will be } \\
\text { wide-known } \\
\text { among tourists. } \\
\text { 2. There is no up- } \\
\text { to-date tourist } \\
\text { information } \\
\text { centers, therefore, } \\
\text { it cannot serve and } \\
\text { provide } \\
\text { information to } \\
\text { tourists very well. } \\
3 . \text { Most of people } \\
\text { lack of knowledge } \\
\text { in tourism, they } \\
\text { are not participate } \\
\text { and not cooperate } \\
\text { in any tourism } \\
\text { aspects. } \\
4 . \text { Most of officers } \\
\text { cannot use the } \\
\text { foreign language } \\
\text { to communicate to } \\
\text { foreign tourists. }\end{array}$ \\
\hline
\end{tabular}




\begin{tabular}{|l|l|l|}
\hline & $\begin{array}{l}\text { as spa, Thai } \\
\text { traditional massage, } \\
\text { and aromatherapy } \\
\text { and so on. }\end{array}$ & \\
\hline
\end{tabular}

After SWOT analysis, researcher made the Tows Matrix Strategy to improve wellness tourism in Chachoengsao and Tows Matrix Strategy is as the following:

\section{Table 2. Tows Matrix Strategy}

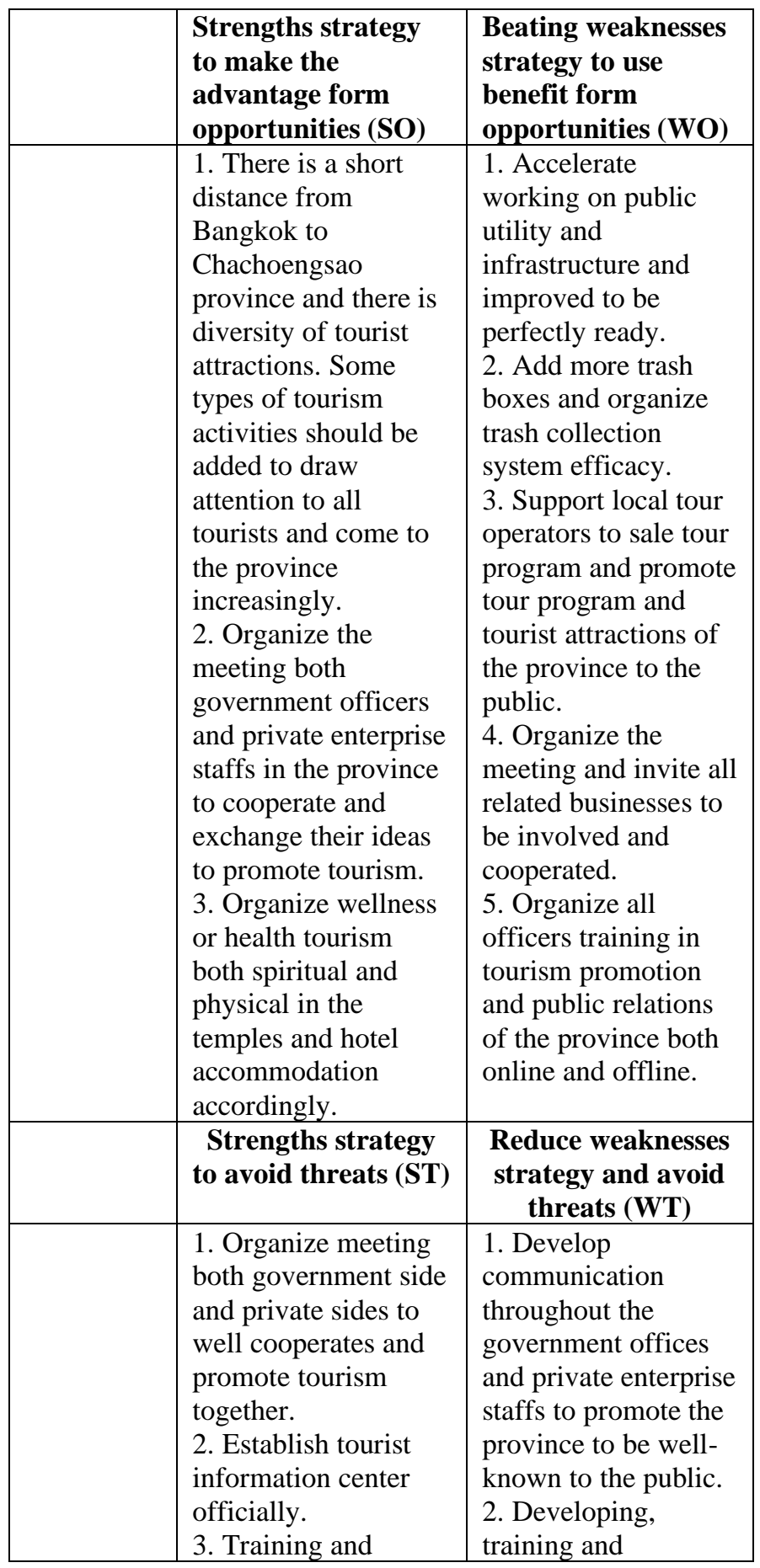

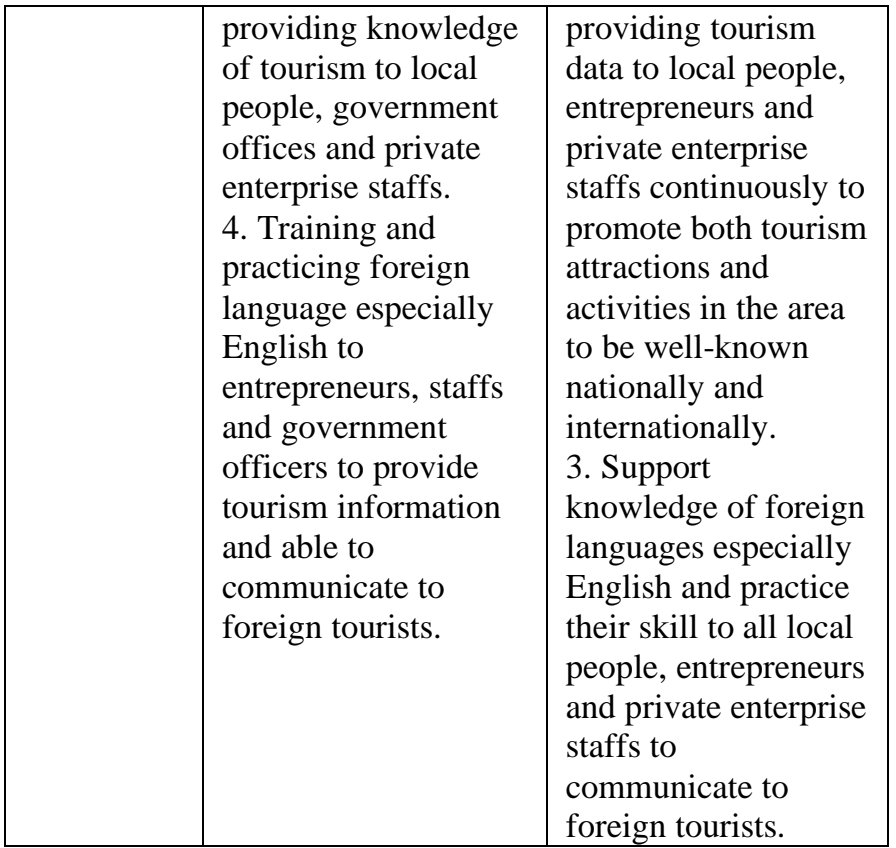

\section{CONCLUSION}

These results served the need of many people travel for resting and relaxation, while a significant number of people also arrive in Thailand to address a medical need of varying urgency. Wellness tourism sits somewhere in between those two drivers of travel. It other locations, wellness tourism is often seen in the form of destination spas. These places feature resort or hotel like conditions but offer a range of holistic health and wellbeing services on-site. People choose these places, not as a simple place of accommodation, but as their main purpose of the holiday. (Pacific Prime Thailand, 2018) Actually, Thailand is ranked 13th in the world and 4th in Asia after China, Japan and India and wellness tourism is an important driver of Thailand's tourism sector, wellness tourism is a star in tourism businesses with over $7 \%$ annual growth during 2013-2015. Its market is valued at 320 billion baht. (Pullawat Pitigraisorn, 2017) Even, there are top 10 of wellness tourism in Thailand, however the locations are too far away mostly are in the southern or the northern part of Thailand and served the rich or classy people. (Luxury Society Asia, 2018) Wellness tourism in Chachoengsao province not only challenge all of the top ten destinations because most of the resorts and hotels provide the wellness service in lower cost and the distance of travel from Bangkok is also very short distance but also can become the new wellness destination in Thailand.

\section{REFERENCES}

Burkart and Melik. (1993). Tourism. London: Butterworth Heinemann. Charumanee, N. (2001). Tourism and Tourism Industry Management. $2^{\text {nd }}$ edition. Bangkok: Odeon Store press.

Chester, C. and Collins, V.R. (1994). Careers in the Travel Industry. $4^{\text {th }}$ Edition, London: Kogan Page.

Chittangwattana, B. (2000). Tour Operator Management. Chiangmai: Faculty of Humanities, Chiang Mai University. 
Chutaporn, S and Cahroensuksai, C. (2001). The Concepts of Tourism in Introduction of Tourism Industry. Bangkok: Sukhothaithammathirat University.

Coleman, Michel M. (1989). Introduction to Travel and Tourism: An International Approach. New York: Van Nostrand Reinhold

Davidoff, P.G. and Davidoff, D.S. (1990). Worldwide Tourism: A Travel Agent's Guide to Selling Tours. New Jersey: Prentice Hall.

Department of Tourism. The Statistic of Tourist Arrival. Retrieved from http://www. tourism.go.th/Index.php on 26 August 2017.

Dervares,C. (1999). Selling Tours and Independent Travel: From the Travel Training Series. Tampa, FL.: Solitaire Publishing.

Foster, D. (1985). Travel and Tourism Management. London: MacMillan Education.

Gee, C.Y. and Staff. (1990). Professional Travel Agency Management. New Jersey: Prentice Hall.

Kamnunwat, D. and Chansawang, W. (1993). Communication: Public Relations. Bangkok:

Chulalongkorn University press.

Khaikaew, S. (2005). The Evaluation of the Need of Ecotourism Management of Bangpru Community, Suratthani Province. The thesis of master degree. Kasetsart

University.

Lamaichin, K. (2009). Cultural Ecotourism. Ubonratchathani:

Ubonratchathani Rachabhat

University.

Mathieson A. and Wall G. (1993). Tourism Economic, Physical and Social Impacts. London: Harlow.

McIntosh, Goeldner and Ritchie. (1997). Tourism Principles, Prentices and Philosophies. London: John Wiley and Sons Inc.

Middleton, V.T. (1988). Marketing in Travel and Tourism. London: Heinemann.

Niyomka, S. (2004). The Potential of Coomunity in Development of Waing Lor to be Cultural Tourism. The independent study of master degree. Chiangmai University.

Peter Mason. (2008). Tourism impacts, Planning and Management. Oxford: Butterworth-Heinemann.

Pimonsompong, C. (1999). Planning and Development of Tourism Marketing. Bangkok: Faculty of Humanities, Kasetsart University.

Reilly, R.T. (1988). Travel and Tourism Marketing Technique. $2^{\text {nd }}$ ed. New York: Delmar Publishers.

Reilly, R.T. (1988). Handbook of Professional Tour Management. New York: Delmar Publishers

Sankam, W. (2002). The Development of Cultural tourism of Ban Pieng Luang, Wienghaeng District, Chiangmai Province. The independent study of master degree. Chiangmai University.

Skyscanner. (2017). Top 10 Provinces of Thailand from Nort to South. Retrived from https://www.skyscanner.co.th/ news/inspiration/thailandpopular- destinations-2016-first-half.on30 September 2016

Sukliang, P. (2002). The development of Cultural Tourism: Case Study of Huaypongphalat

Village, Wiangpapao District, Chiangrai Province. The independent study of master degree. Chiangmai University.

Tongoeiam, N. (2009). Cultural Tourism Potential Development of Kantang District, Trang Province. The independent study of master degree, Rangsit University. 